\title{
Accumulation and enrichment of platinum group elements in hydrogenous Fe-Mn crust and nodules from the Andaman Sea, India
}

\author{
Saju Varghese ${ }^{1, *}$, Rajani P. Ramesh ${ }^{1}$, Rachna Pillai ${ }^{1}$, Sethu Rose Joseph ${ }^{2}$, \\ B. Gopakumar ${ }^{1}$, Resmi Sathikumar ${ }^{3}$, Rajesh Kumar Joshi ${ }^{3}$, \\ Priyanka Dey Guha ${ }^{3}$, R. V. Manoj ${ }^{1}$ and M. Nagasundaram ${ }^{3}$ \\ ${ }^{1}$ Geological Survey of India, Op: WC-I, Southern Region, Mangalore 575 001, India \\ ${ }^{2}$ Geological Survey of India, Op: WC-II, Southern Region, Cochin 682 037, India \\ ${ }^{3}$ Geological Survey of India, Eastern Region, Kolkata 700 091, India
}

Present study explores the processes influencing the concentration, mechanism of incorporation and sources of Platinum Group of Elements (PGE) in hydrogenous ferromanganese crusts and nodules (hereafter crusts and nodules) from the West Sewell Ridge and Sewell Rise in the Andaman Sea. $\sum$ PGE content is lower in nodules (633 ppb) as compared to crusts (average $=1284 \mathrm{ppb}$ ) due to the diagenetic influence. The chondrite-normalized PGE patterns of crusts and nodules demonstrate consistent Platinum (Pt) enrichment and Palladium (Pd) depletion. We suggest that $\mathrm{Pt}$, Iridium (Ir), and Ruthenium (Ru) are scavenged from seawater by sorption and oxidation on $\delta-\mathrm{MnO}_{2}$ surfaces of suspended ferromanganese oxyhydroxides. However, non-correlation of $P d$ with other trace elements revealed its nonaccumulation in crusts and nodules. Different PGE ratios reveled that Ir and Pd originated largely from a cosmogenic source and $R u, R h$, and $P t$ were probably sourced from ophiolites in the Andaman Accretionary Prism.

Keywords: Accumulation and enrichment, crusts, hydrogenous ferromanganese deposits, nodules, platinum group elements.

FERROMANGANESE crusts and nodules (hereafter crusts and nodules) are one of the critical offshore mineral resources for metals ${ }^{1,2}$. Reports of high concentration (up to 1-3 ppm) and distribution of platinum in the Central Pacific and ANS seamount crusts and nodules enriched in oxyhydroxide minerals have gained considerable attention $^{3-6}$. The sources of platinum group of elements (PGE) in seawater, which occur in dissolved as well as in particulate forms, are terrestrial and cosmogenic inputs ${ }^{7,8}$. Among the PGE, though the concentration of palladium $(\mathrm{Pd})$ and platinum $(\mathrm{Pt})$ is the same, crusts and nodules are noted for non-accumulation of $\mathrm{Pd}^{7,8}$. Further, it is to be

*For correspondence. (e-mail: saajuvarghese@gmail.com) noted that the behaviour of ruthenium $(\mathrm{Ru})$ and iridium (Ir) in the marine environment has not been well documented $^{9,10}$. Due to the close association of PGE with organic ligands in seawater, it is enriched (in the order: $\mathrm{Ir}>\mathrm{Ru}>\mathrm{Pt}>\mathrm{Pd}$ ) in hydrogenous crusts and nodules in comparison to diagenetic nodules and hydrothermal crusts $^{6,11,12}$. Numerous studies have suggested that the mechanism of incorporation of platinum into crusts and nodules is sorption from seawater and consequent redox reactions on ferromanganese oxyhydroxides ${ }^{7,6,11,13,14}$, and the incorporation of noble metals in fine-grained particles from cosmic source ${ }^{15,16}$. Though PGE distribution in crusts is well documented ${ }^{6,17-20}$, PGE distribution studies in the nodules are limited ${ }^{11,12}$.

Numerous seamounts are located in the Andaman Sea, India, in association with the tectonics of backarc spreading ${ }^{21}$. Surya Prakash et al. $^{22}$ reported crust occurrences in the inner volcanic arc system in the Andaman $\mathrm{Sea}^{22}$. Sporadic occurrences of crusts and nodules have also been reported on the West Sewell Ridge (WSR) and Sewell Rise (SR) in the Andaman Sea ${ }^{23}$. Hence, in the present study, we report PGE data of four bulk samples from the crusts and nodules in the Andaman Sea, along with mineralogical and chemical data to understand the causes for platinum accumulation and enrichment.

\section{Materials and methods}

To explore the occurrence of crusts and nodules, a cruise SR-45 on-board R.V. Samudra Ratnakar was undertaken in the southern part of WSR and SR (Figure 1). Among the undisturbed samples collected using the remotely operating vehicle (ROV) manipulator, two samples from WSR (one crust and one nodule) and two crust samples from SR were analysed for mineralogy, major oxides, trace elements, rare earth elements (REE), and PGE. The on-board prepared 3D grid model from the MBES survey 

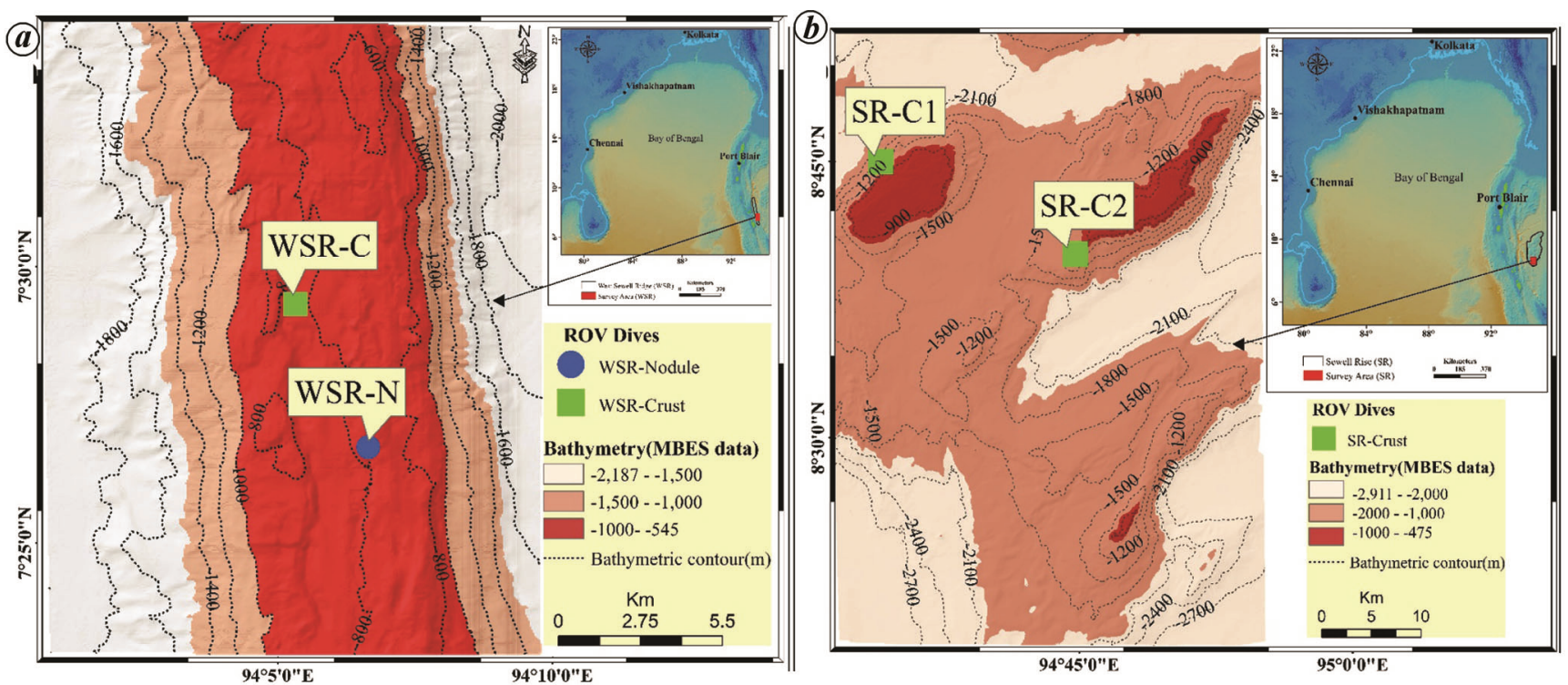

Figure 1. Location map of the study area: (a) West Sewell Ridge and (b) Sewell Rise, Andaman Sea, India. Crusts is represented as a green square, whereas nodule as a blue circle.

and sub-bottom profiles during cruise SR-45 were used to determine the ROV dive locations (Figure 1).

PGE in the crusts and nodules were enriched using $\mathrm{Ni}$ fire assay method ${ }^{4}$. An aliquot of sample powder $(\sim 10$ g) was mixed with a flux (made of soda ash, borax, silica, sulphur, and nickel carbonate) and fused at $1200^{\circ} \mathrm{C}$ in a muffle furnace. The fused mixture of $\mathrm{Ni}, \mathrm{PGE}$ and $\mathrm{Au}$ sulphides was treated with $\mathrm{HCl}$ to remove $\mathrm{Ni}$. The remaining $\mathrm{PGE}$ and $\mathrm{Au}$ after $\mathrm{HCl}$ treatment were dissolved in aqua regia in a borosilicate test tube and diluted with nitric acid to the required volume for measurement. PGE measurements were carried out using an inductively coupled mass spectrometer (ICP-MS) at the National Geophysical Laboratory (NGRI), Hyderabad $^{4}$.

The major oxides and trace elements were analysed using inductively coupled plasma-optical emission spectrometry (ICP-OES) at the Chemical Division, Geological Survey of India (GSI), Kolkata. The ICP-OES instrument was calibrated using the standards GSD 10, GSD 12, GSS 2, GSS 4, GSS 5 and GSS 7 for various elements. REE analyses of the samples were also done at GSI, Kolkata, with analytical precision better than $1.5 \%$. Triple acid digestion method was used to make a solution of the samples for analyses. Mineralogy of the crusts and nodules was determined by X-ray diffraction (XRD) using a diffractometer (Philips) with $\mathrm{CuK}_{\alpha}$ radiation and a graphite monochromator at GSI, Kolkata. PANalytical software packages and inorganic minerals database were used to interpret the XRD spectra. The detection limit for minerals ranged between $0.2 \%$ and $1.0 \%$; however, for manganese mineral (i.e. $\delta-\mathrm{MnO}_{2}$ ) detection limit ranged up to $10 \%$.

\section{Results}

\section{Mineralogy}

Mineral composition of the studied nodules showed relative enrichment of todorokite (10 $\AA$ manganate mineral) as a major constituent along with accessory minerals such as quartz, plagioclase and calcite (Figure 2). On the other hand, crusts, contained more $\delta-\mathrm{MnO}_{2}$ as a major constituent in different layers along with todorokite in good amounts, while the accessory minerals present were quartz and feldspar (Figure 2). Hence, the studied nodules were dominated by todorokite while the crusts on WSR consisted dominantly of $\delta-\mathrm{MnO}_{2}$.

\section{Major oxides and trace elements}

In the nodules, concentration of Fe was $13.60 \%$ and $\mathrm{Mn}$ was $23.00 \%$, with $\mathrm{Mn} / \mathrm{Fe}$ ratio of $1.69(n=1)$ (Table 1 and Figure 3 ). In the crusts, concentration of Fe (average $21.50 \mathrm{wt} \%$ ) was higher than $\mathrm{Mn}$ (average $16.88 \mathrm{wt} \%$ ), with average $\mathrm{Mn} / \mathrm{Fe}$ ratio of $0.79(n=3)$. Hence the concentration of $\mathrm{Fe}$ was more in the crusts compared to the nodules which had higher concentration of Mn (Figure 3). The concentration of $\mathrm{Al}$ in the crusts (average $2.44 \mathrm{wt} \%$; $n=3$ ) was less compared to the nodules (3.89 $\mathrm{wt} \%$; $n=1)$. It is to be noted that the average concentration of Ti $(0.30 \% ; n=3)$ was higher in the crusts compared to the nodules $(0.20 \mathrm{w} \% ; n=1)$. $\mathrm{Na}$ and $\mathrm{Ca}$ were slightly enriched in the crusts $(\mathrm{Na}=$ average $2.28 \mathrm{wt} \%(n=3)$; $\mathrm{Ca}=$ average $3.15 \mathrm{wt} \%(n=3))$ compared to the nodules $\left(\mathrm{Na}=1.98 \mathrm{wt}^{2} \%(n=1) ; \mathrm{Ca}=1.15 \mathrm{wt} \%(n=1)\right)$. On the 
other hand, $\mathrm{K}$ and $\mathrm{Mg}$ were slightly enriched in the nodules $(\mathrm{K}=1.35 \mathrm{wt} \%(n=1) ; \mathrm{Mg}=3.47 \mathrm{wt} \%(n=1))$ compared to the crusts $(\mathrm{K}=$ average $1.11 \mathrm{wt} \%(n=3)$; $\mathrm{Mg}=$ average $2.03 \mathrm{wt} \%(n=3))$.

Among the minor elements (Table 1), Co was enriched in the crusts as its concentration range from $0.17 \%$ to $0.18 \mathrm{wt} \%(n=3)$ whereas it was $0.11 \mathrm{wt} \%$ in the nodules $(n=1$; Figure 4$)$. The average $\mathrm{Ni}$ concentration in the crust was $0.24 \mathrm{wt} \%(n=3)$, whereas in the nodules it was $0.52 \mathrm{wt} \%(n=1)$. Average $\mathrm{Cu}$ and $\mathrm{Zn}$ concentrations (161 and $385 \mu \mathrm{g} / \mathrm{g}$ respectively; $n=3$ ) were less in the

Table 1. Major oxides (\%) and trace elements (ppm) concentration in nodules and crusts in the Andaman Sea, India

\begin{tabular}{|c|c|c|c|c|}
\hline \multirow[b]{2}{*}{ Sample } & \multicolumn{2}{|c|}{ West Sewell ridge } & \multicolumn{2}{|c|}{ Sewell rise } \\
\hline & WSR-N & WSR-C & SR-C1 & SR-C2 \\
\hline $\mathrm{Mn}$ & 23.00 & 15.40 & 18.17 & 17.07 \\
\hline $\mathrm{Fe}$ & 13.60 & 21.30 & 22.45 & 20.74 \\
\hline $\mathrm{Mn} / \mathrm{Fe}$ & 1.69 & 0.72 & 0.81 & 0.82 \\
\hline $\mathrm{Al}$ & 3.89 & 3.52 & 1.62 & 2.19 \\
\hline $\mathrm{Na}$ & 1.98 & 1.94 & 2.59 & 2.30 \\
\hline K & 1.35 & 1.14 & 1.07 & 1.12 \\
\hline $\mathrm{Mg}$ & 3.47 & 2.43 & 1.82 & 1.84 \\
\hline $\mathrm{Ca}$ & 1.15 & 3.69 & 2.91 & 2.85 \\
\hline $\mathrm{Ti}$ & 0.20 & 0.25 & 0.29 & 0.35 \\
\hline $\mathrm{P}$ & 0.34 & 0.86 & 0.87 & 0.90 \\
\hline $\mathrm{Sc}$ & 8.79 & 11.95 & 13.21 & 14.19 \\
\hline V & 947.49 & 2571.68 & 2002.76 & 2013.78 \\
\hline $\mathrm{Cr}$ & 36.59 & 33.42 & 33.48 & 55.82 \\
\hline $\mathrm{Co}$ & 1190.51 & 1701.98 & 1752.04 & 1878.01 \\
\hline $\mathrm{Ni}$ & 3085.56 & 1531.12 & 3114.33 & 2764.93 \\
\hline $\mathrm{Cu}$ & 276.95 & 330.22 & 757.17 & 583.12 \\
\hline $\mathrm{Zn}$ & 595.52 & 733.98 & 771.01 & 561.63 \\
\hline $\mathrm{Ga}$ & 17.22 & 11.81 & 12.90 & 17.96 \\
\hline $\mathrm{Rb}$ & 23.09 & 19.63 & 37.26 & 25.46 \\
\hline $\mathrm{Sr}$ & 603.46 & 1093.84 & 1192.35 & 777.74 \\
\hline $\mathrm{Y}$ & 73.79 & 236.65 & 280.11 & 251.90 \\
\hline $\mathrm{Zr}$ & 186.86 & 361.16 & 381.54 & 442.45 \\
\hline $\mathrm{Nb}$ & 22.98 & 43.92 & 46.58 & 61.15 \\
\hline Cs & 1.33 & 0.97 & 1.69 & 1.66 \\
\hline $\mathrm{Ba}$ & 3341.88 & 1736.69 & 1319.77 & 2031.24 \\
\hline Hf & 3.47 & 5.26 & 5.76 & 8.16 \\
\hline $\mathrm{Ta}$ & 0.49 & 0.29 & 0.19 & 0.34 \\
\hline $\mathrm{Pb}$ & 1771.96 & 3791.05 & 4621.92 & 4603.85 \\
\hline $\mathrm{Th}$ & 28.86 & 56.38 & 80.43 & 88.43 \\
\hline $\mathrm{U}$ & 3.86 & 7.00 & 7.24 & 4.82 \\
\hline $\mathrm{La}$ & 66.94 & 192.22 & 258.61 & 219.49 \\
\hline $\mathrm{Ce}$ & 378.55 & 670.13 & 816.73 & 908.48 \\
\hline $\operatorname{Pr}$ & 16.77 & 47.82 & 63.83 & 52.14 \\
\hline $\mathrm{Nd}$ & 58.77 & 171.41 & 224.11 & 185.80 \\
\hline $\mathrm{Sm}$ & 13.83 & 40.58 & 52.64 & 43.96 \\
\hline $\mathrm{Eu}$ & 3.76 & 10.10 & 12.57 & 11.16 \\
\hline $\mathrm{Gd}$ & 15.02 & 43.32 & 53.18 & 47.53 \\
\hline $\mathrm{Tb}$ & 2.29 & 7.12 & 8.63 & 7.76 \\
\hline DY & 12.36 & 39.35 & 46.88 & 41.64 \\
\hline Но & 2.57 & 8.30 & 9.76 & 8.89 \\
\hline $\mathrm{Er}$ & 7.09 & 22.97 & 26.68 & 25.20 \\
\hline $\mathrm{Tm}$ & 0.93 & 3.01 & 3.45 & 3.39 \\
\hline $\mathrm{Yb}$ & 5.91 & 18.79 & 21.18 & 20.38 \\
\hline $\mathrm{Lu}$ & 0.85 & 2.66 & 2.96 & 2.90 \\
\hline$\sum \mathrm{REE}$ & 585.63 & 1277.79 & 1601.19 & 1578.71 \\
\hline
\end{tabular}

crusts compared to the nodules (470 and $421 \mu \mathrm{g} / \mathrm{g}$ respectively; $n=1)$. In general, crusts in the Andaman Sea are enriched with $\mathrm{Co}$ and depleted in $\mathrm{Ni}, \mathrm{Cu}$ and $\mathrm{Zn}$, compared to the nodules.

\section{REE geochemistry}

The analysed nodules $(n=1)$ contained less $\sum$ REE concentration $(585 \mathrm{ppm})$ compared to the crusts (1277-

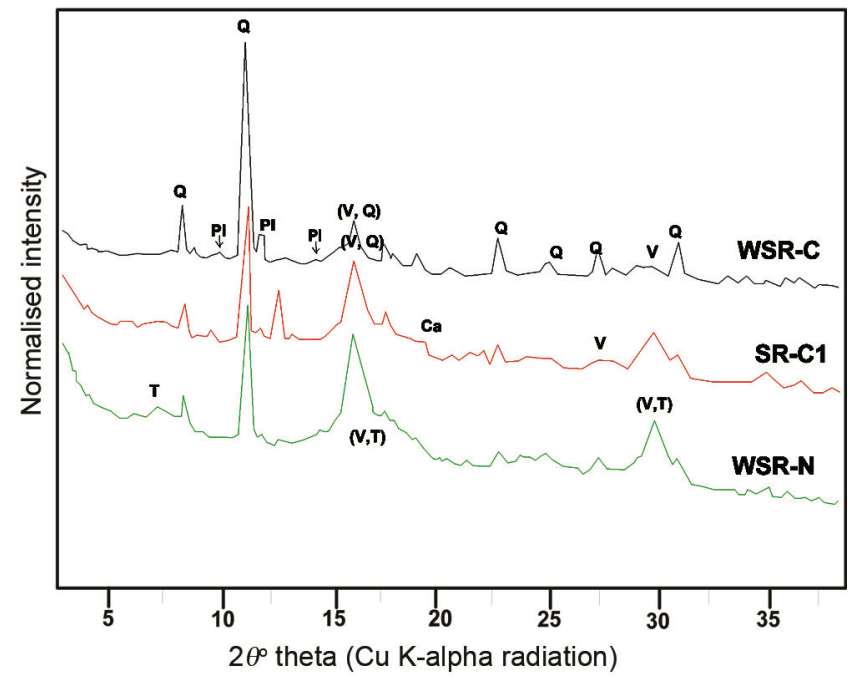

Figure 2. X-ray diffraction patterns of crusts and nodules in the Andaman Sea. V, Vernadite; T, Todorokite; Q, Quartz; Pl, Plagioclase; $\mathrm{Ca}$, Calcite.
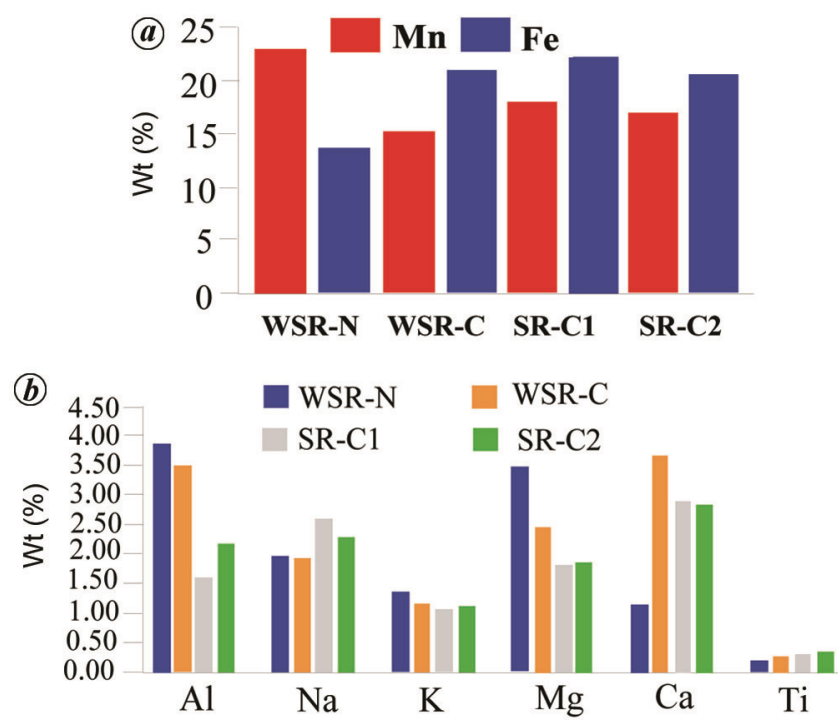

Figure 3. a, Bar diagram showing the bulk concentration of $\mathrm{Fe}$ and $\mathrm{Mn}$ in nodules and crusts. In the nodule (WSR-N), concentration of $\mathrm{Mn}$ is higher than Fe, whereas the crust (WSR-C, SR-C1 and SR-C2) shows higher Fe concentration compared to $\mathrm{Mn}$. $\boldsymbol{b}$, Bar diagram showing the bulk concentration of other major elements in the nodules and crusts. $\mathrm{Al}$ is significantly high in the nodules, whereas other major elements are high in the crusts. 


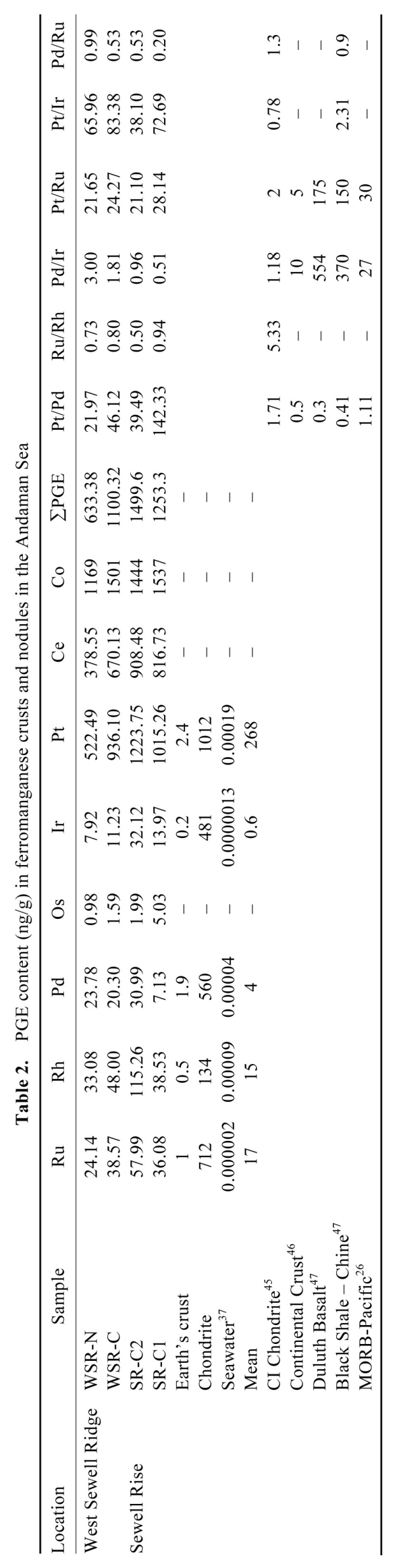


$1601 \mathrm{ppm}(n=3)$ : average $1485 \mathrm{ppm}(n=3)$ (Table 1$)$. It is to be noted that the nodules and crusts possess high $\mathrm{Ce}$ content in $\sum$ REE compared to other REEs (51-64\%; average $=56 \%$ ). The PAAS-normalized REE patterns of the crusts and nodules showed strongly positive $\mathrm{Ce}$ anomalies ( $\delta \mathrm{Ce}: 2.56$ in the nodules and $\delta \mathrm{Ce}: 1.75-2.3$; average 2.07 in the crusts) (Figure 5). Slightly greater HREE fractionation over LREE is indicated by $(\mathrm{La} / \mathrm{Sm})_{N}$ $\left((\mathrm{La} / \mathrm{Sm})_{N}=0.69\right.$ in the nodules and $(\mathrm{La} / \mathrm{Sm})_{N}=0.68$ (average) in the crusts).

\section{Platinum group elements}

The new geochemical data show that the Andaman Sea crusts and nodules depict relatively high total PGE contents ( $\sum$ PGE: $633 \mathrm{ng} / \mathrm{g}$ in the nodules $(n=1) ; 1100$ $1499 \mathrm{ng} / \mathrm{g} \quad($ average $=1284 \mathrm{ppb})$ in the crusts $(n=3))$ (Table 2). In WSR, platinum content was $522 \mathrm{ng} / \mathrm{g}$ in the nodules, whereas in the crust the concentration increased up to $936 \mathrm{ng} / \mathrm{g}$ (Table 1). Further, Ru, Rh, Pd, Ir and $\mathrm{Au}$ ranged from 24 to $38 \mathrm{ng} / \mathrm{g}, 33$ to $47 \mathrm{ng} / \mathrm{g}, 20$ to $23 \mathrm{ng} / \mathrm{g}$, 7.9 to $11.227 \mathrm{ng} / \mathrm{g}$, and 91 to $112 \mathrm{ng} / \mathrm{g}$ in the WSR crusts

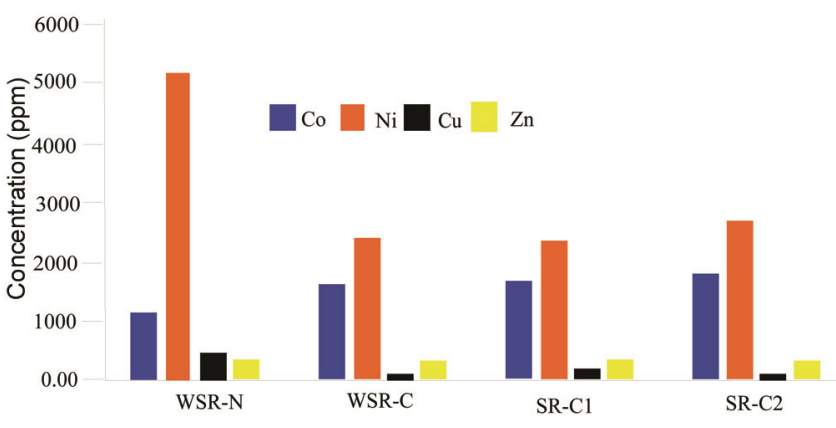

Figure 4. Bar diagram showing the bulk concentration of selected trace elements, viz. $\mathrm{Co}, \mathrm{Ni}, \mathrm{Cu}$ and $\mathrm{Zn}$. In the nodule (WSR-N), $\mathrm{Ni}, \mathrm{Cu}$ and $\mathrm{Zn}$ are high compared to the crust (WSR-C, SR-C1 and SR-C2), whereas Co concentration is higher in the crust compared to the nodule.

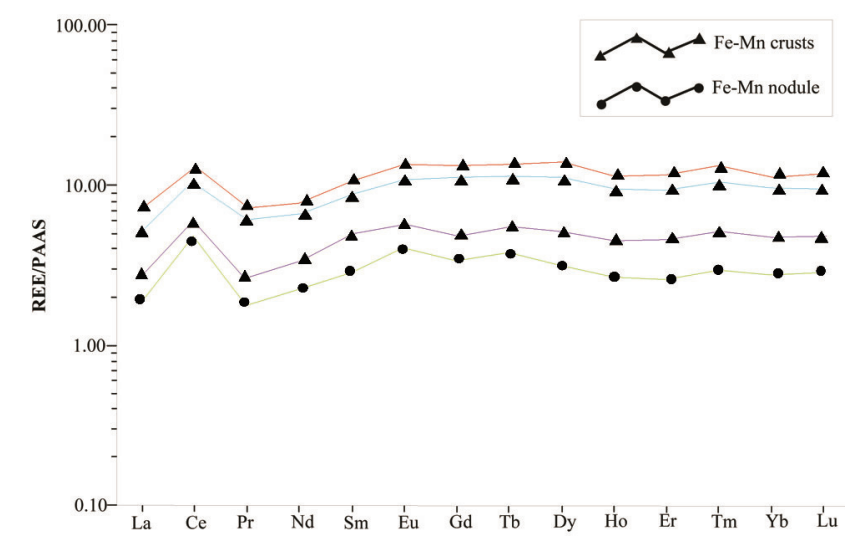

Figure 5. REE distribution patterns of nodules and crusts (PAAS normalized $)^{48}$. REE patterns show strong positive Ce anomalies, indicative of dominant hydrogenetic component in the studied samples. and nodules respectively. On the other hand, in the crusts of SR, a high Pt value of 1015-1223 ng/g was found in the crusts. $\mathrm{Ru}$ varied from 36 to $57 \mathrm{ng} / \mathrm{g}, \mathrm{Rh}$ from 38 to $115 \mathrm{ng} / \mathrm{g}, \mathrm{Pd}$ from 7 to $30 \mathrm{ng} / \mathrm{g}$, and Ir from 13 to $32 \mathrm{ng} / \mathrm{g}$ in the SR crusts. There was significant difference in $\mathrm{Pt}$ content in the crusts compared to the nodules; in general, $\mathrm{Pt}$ content in the crusts (average of $1.058 \mathrm{ppm} ; n=3$ ) is higher than in the nodules $(0.5 \mathrm{ppm} ; n=1)$. In the studied samples, $\mathrm{Pt} / \mathrm{Pd}$ ratios varied from 22 to 142 . Compared to average seawater, Pt was enriched by a factor between $10^{6}$ and $10^{7}$, while Pd displayed enrichment in the order of 10 (ref. 24).

\section{Element correlations}

Elemental correlation revealed that Ce was significantly highly correlated with $\mathrm{Ru}(r=0.86), \mathrm{Ir}(r=0.78)$ and $\mathrm{Pt}$ $(r=0.98)$ (Table $3 ; n=4)$. However, Co showed a high correlation with Os $(r=0.90)$ and $\mathrm{Ce}(r=0.79)$, and moderate correlation with $\mathrm{Pt}(r=0.69)$. On the other hand, Rh showed a high correlation with $\operatorname{Ir}(r=0.97)$ and Pt $(r=0.75)$ and Os was highly negatively correlated with Pd $(r=-0.81)$. Pd did not correlate with other PGE as well as with Co and Ce.

\section{Discussion}

\section{Processes influencing variations of PGE contents in nodules and crusts}

The REE patterns were used to differentiate the various processes (hydrothermal, diagenetic and hydrogenetic) involved in the genesis of nodules and crusts ${ }^{25}$. PAASnormalized REE plots of the crusts and nodules are typical hydrogenetic crust plots with a distinct positive $\mathrm{Ce}$ anomaly (Figure 5$)^{25,26}$. In the $\mathrm{Fe}-\mathrm{Mn}-(\mathrm{Cu}+\mathrm{Ni}+\mathrm{Co}) * 10$ triangular $\operatorname{plot}^{27}$, the analysed crusts and nodules fall within the hydrogenetic field (Figure 6). The hydrogenetic REE patterns of crusts and nodules with positive Ce anomaly and plotting of the samples in the hydrogenetic field of $\mathrm{Fe}-\mathrm{Mn}-(\mathrm{Cu}+\mathrm{Ni}+\mathrm{Co}) * 10$ triangular plot suggest that the analysed nodules and crusts are dominantly hydrogenetic precipitates. However, identification of the characteristic diagenetically derived mineral, i.e. $10 \AA$ manganate in the nodules indicates diagenetic contribution along with dominant hydrogenetic input in the nodule formation ${ }^{28}$. Further, higher concentration of $\mathrm{Mn}$ compared to $\mathrm{Fe}(\mathrm{Mn} / \mathrm{Fe}=1.69)$ in the nodules indicate a diagenetic input and the absence of hydrothermal input. Hence, the dominant processes influencing PGEenrichment in the Andaman Sea crusts and nodules are hydrogenetic processes in crusts and nodules. The low concentration of $\mathrm{Pt}$ in hydrogenous nodules than in the crusts is due to contribution from PGE poor diagenetic 
Table 3. Correlation coefficients of PGE and trace elements in crusts and nodules in the Andaman Sea

\begin{tabular}{llrrrrrrr}
\hline & $\mathrm{Ru}$ & $\mathrm{Rh}$ & $\mathrm{Pd}$ & $\mathrm{Os}$ & $\mathrm{Ir}$ & $\mathrm{Pt}$ & $\mathrm{Ce}$ & $\mathrm{Co}$ \\
\hline $\mathrm{Ru}$ & 1 & & & & & & & \\
$\mathrm{Rh}$ & 0.945 & 1 & & & & & & \\
$\mathrm{Pd}$ & 0.451 & 0.682 & 1 & & & & & \\
$\mathrm{Os}$ & 0.080 & -0.150 & -0.812 & 1 & & & & \\
$\mathrm{Ir}$ & 0.953 & 0.976 & 0.526 & 0.059 & 1 & & & \\
$\mathrm{Pt}$ & 0.920 & 0.750 & 0.069 & 0.426 & 0.820 & 1 & & \\
$\mathrm{Ce}$ & 0.863 & 0.677 & -0.060 & 0.560 & 0.780 & 0.987 & 1 & \\
$\mathrm{Co}$ & 0.448 & 0.274 & -0.485 & 0.904 & 0.473 & 0.687 & 0.794 & 1 \\
\hline
\end{tabular}

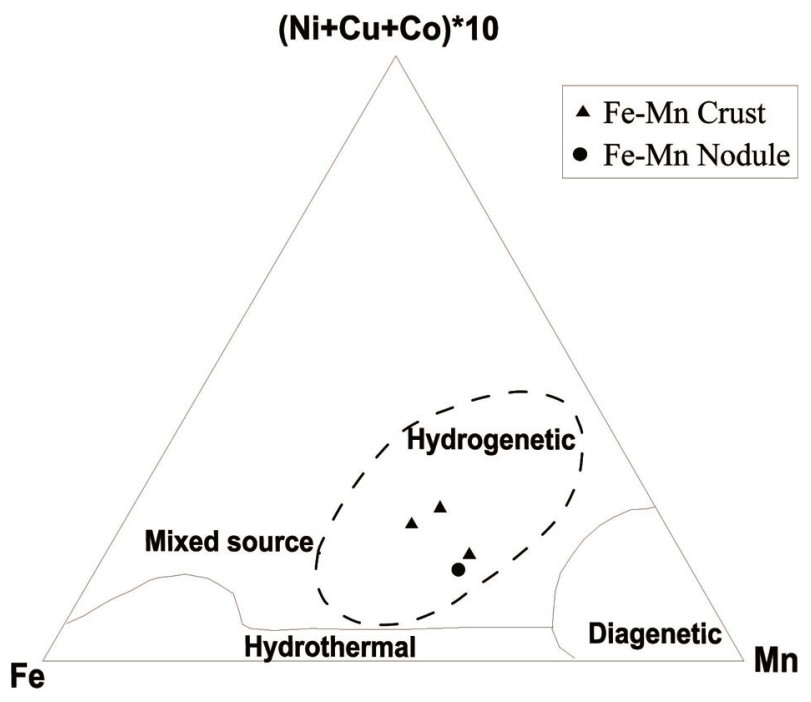

Figure 6. Ternary plot of $\mathrm{Fe}-\mathrm{Mn}-(\mathrm{Cu}+\mathrm{Ni}+\mathrm{Co})^{*} 10, \mathrm{Fe}$ and $\mathrm{Mn}$ illustrating genesis of nodules and crusts ${ }^{27}$. Note that crusts and nodules fall within the hydrogenetic field.

material supply in to the nodules and consequent low $\mathrm{Pt}$ flux in the nodule ${ }^{29}$. Further, PGE enrichment due to hydrothermal activity is negated in the Andaman Sea crusts and nodules ${ }^{7,30}$.

\section{Mechanism of incorporation of $P G E$}

Several studies have proposed that oxidation on $\delta-\mathrm{MnO}_{2}$ surfaces is responsible for coincident precipitation of PGE in the crusts and nodules ${ }^{3,7}$. However, some studies have postulated that absorption or adsorption followed by oxidation of platinum ( $\mathrm{Pt}(\mathrm{II}) \rightarrow \mathrm{Pt}(\mathrm{IV})$ ) on manganese oxide also fixed $\mathrm{Pt}$ in the crusts and nodules ${ }^{31-35}$. Platinum hydroxo-chloro (II) and (IV) complexes react with freshly precipitated $\mathrm{Fe}-\mathrm{Mn}$ oxyhydroxides over a long time and enriched in $\mathrm{PGE}^{12}$.

In seawater, $\mathrm{Mn}$ oxides oxidize $\mathrm{Co}(\mathrm{II})$ and $\mathrm{Ce}(\mathrm{III})$ to poorly soluble $\mathrm{Co}(\mathrm{III})$ and $\mathrm{Ce}(\mathrm{IV})$. It has been established that there is a close correlation between PGE (especially $\mathrm{Pt}$ ) and hydrogenetically derived trace elements (e.g. Co and $\mathrm{Ce}$ ) in the case of PGE accumulation from seawater through oxidative reaction ${ }^{6-8}$. Similarly, in the Andaman
Sea nodules and crusts, Pt correlates with redox-sensitive elements such as $\mathrm{Co}$ and $\mathrm{Ce}$. The close correlation of Co and $\mathrm{Ce}$ with $\mathrm{Pt}$ indicates similarities in the process of incorporation in the crusts and nodules. Hence, close correlation of $\mathrm{Co}$ and $\mathrm{Ce}$ with $\mathrm{Pt}$ indicates that the enrichment is due to sorption and subsequent oxidation of $\mathrm{Pt}^{8,14}$.

Similar to $\mathrm{Pt}, \mathrm{Ce}$ is significantly highly correlated with $\mathrm{Ru}(r=0.86)$ and $\mathrm{Ir}(r=0.78)$. Koide et al. ${ }^{9}$ identified two stable states of oxidation, viz. Ru (III), Ru (IV), Ir (III) and Ir (IV). Hence, similar to Pt, the mechanism through which these elements are incorporated could be oxidative (Ir(III) $\rightarrow \operatorname{Ir}(\mathrm{IV})$ and $\mathrm{Ru}(\mathrm{III}) \rightarrow \mathrm{Ru}(\mathrm{IV}))$ absorption or adsorption on suspended Fe and Mn oxyhydroxides $^{9,29}$.

\section{Sources of PGE in $\mathrm{Fe}-\mathrm{Mn}$ crusts and nodules}

PGE in seawater are either derived from terrestrial or from cosmogenic inputs ${ }^{7,31}$. PGE sources in the ocean are from continental-derived rivers, hydrothermal activities, cosmic source and halmyrolysis of oceanic basalts ${ }^{32-34}$ Due to the occurrence of PGE in dissolved and particulate forms, deviation of PGE concentration in crusts and nodules points towards the provenance of metal supply ${ }^{7,8}$. Hence, a comparative study of the different ratios of PGE in the Andaman Sea crusts and nodules with probable source materials was used to understand the sources of PGE.

Chondrite-normalized PGE patterns of the Andaman Sea crusts and nodules demonstrated consistent $\mathrm{Pt}$ enrichment and $\mathrm{Pd}$ depletion over other PGE. Pt/Pd ratios in the Andaman Sea nodules and crusts ranged between 21 and 142 and were in accordance with global abundance of $\mathrm{Pt}$ and $\mathrm{Pd}$ in nodules and crusts ${ }^{6,8,31,35,36}$. Further, $\mathrm{Pt} / \mathrm{Pd}$ ratio revealed that $\mathrm{Pt}$ was exclusively incorporated into $\mathrm{Fe}-\mathrm{Mn}$ precipitates than $\mathrm{Pd}$. This enrichment of $\mathrm{Pt}$ over $\mathrm{Pd}$ in the crusts and nodules $(\mathrm{Pt} / \mathrm{Pd}=21-142)$ when compared to $\mathrm{Pt} / \mathrm{Pd}$ ratio in seawater $(\sim 4-5)$ explains the oxidation of $\mathrm{Pt}$, similar $\mathrm{Ce}$ and $\mathrm{Co}$ and consequent enrichment of $\mathrm{Pt}$ with time and due to slow growth rate $(\text { Table } 2)^{37}$. 


\section{RESEARCH ARTICLES}

Koide et $a l .{ }^{38}$ highlighted that strong extraterrestrial influence is required for covariance of Pd with other PGE. Considering this, Pd-depleted chondrite-normalized PGE pattern of the crusts and nodules was found to effectively negate the cosmic source for PGE in these hydrogenic crusts and nodules (Figure 7). Further, if the cosmogenic input is dominant, such crusts and nodules are distinguished by abnormal PGE concentration ${ }^{38}$. Here, the contribution of PGE from cosmogenic source is negated due to regular distribution of PGE, a clear relationship between PGE and other trace elements, and a dominant Pd depletion in the chondrite-normalized PGE pattern ${ }^{8}$.

Banakar et $a l .{ }^{6}$ documented extraterrestrial source for $\mathrm{Pd}$ and Ir owing to the depletion of $\mathrm{Pd}$ in the chondritenormalized PGE pattern and similarity of $\mathrm{Pd} / \mathrm{Ir}$ ratios in the crusts to that of CI-chondrites $(\sim 1)$. The depletion of $\mathrm{Pd}$ in the chondrite-normalized PGE patterns of crusts and nodules along with $\mathrm{Pd} / \mathrm{Ir}$ ratios similar to CIchondrites (i.e. $\sim 1$ ) suggest dominantly an extraterrestrial source for Pd and Ir. This argument is supported by the significant deviation of $\mathrm{Pd} / \mathrm{Ir}$ ratio in the Andaman Sea crusts and nodules compared to the continental and oceanic crusts (Table 2). Further, non-correlation of Pd with other elements was linked to the non-deposition of $\mathrm{Pd}$ in the oxyhydroxide part of the crusts and nodules ${ }^{7,8,29}$.

On the other hand, $\mathrm{Ru} / \mathrm{Rh}, \mathrm{Pt} / \mathrm{Ir}$ and $\mathrm{Pt} / \mathrm{Ru}$ ratios were similar to continental crust and different from that of meteorites. Major sediment sources to the Andaman Sea are the Irrawaddy Delta, western slopes of the Andaman Accretionary Prism (AAP) and catchments of Salween and Sittang and the Bengal Shelf ${ }^{21,39,40}$. Hence, the detrital component in the Andaman Sea crusts and nodules is mostly derived from chemical weathering of continental crusts and from the input of local volcanogenic sources. However, PGE contribution to the Andaman Sea crusts and nodules from the detrital input is negated due to its low concentration in the continental crust. Further, the substrate rocks neither provide fluids for crusts nor diagenetically influence their composition ${ }^{6}$.

PGE are concentrated (in ppm level) in a number of ophiolite complexes globally (e.g. Scottish Shetland ophiolite $)^{41}$. In the AAP, the ophiolites occur as north-

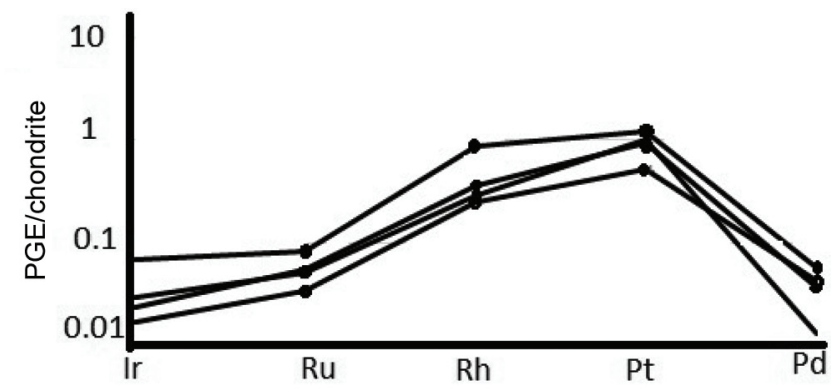

Figure 7. CI chondrite-normalized PGE patterns of the crusts and nodules from the Andaman Sea showing Pt enrichment and Pd depletion ${ }^{49}$. south trending slices of Cretaceous-Palaeocene oceanic basement lying over the Paleogene flysch deposited in the Andaman fore-arc basin ${ }^{42}$. The total PGE content in AAP ophiolite varied between 11.6 and $41.2 \mathrm{ppb}^{43}$. Chromite placers off Rutland coast of AAP showed PGE incidence, and serpentinized dunite in the AAP was the source rock of the chromite placers ${ }^{44}$. Hence, it is postulated that the higher concentration of $\mathrm{Pt}$ along with $\mathrm{Ru}$ and $\mathrm{Rh}$ in the crusts and nodules is possibly derived from the chemical weathering of ophiolites exposed in AAP. Hence, PGE ratios indicate that $\mathrm{Ir}$ and $\mathrm{Pd}$ in the Andaman Sea crusts and nodules are originated largely from a cosmogenic source whereas $\mathrm{Pt}$, Ir and Pd are possibly contributed by ophiolites present in AAP. Although, there may be other PGE sources to the Andaman Sea crusts and nodules, their influence could not be deciphered in the present study.

\section{Conclusion}

Sub-equal amounts of Fe and Mn, PAAS normalized REE pattern with high positive $\mathrm{Ce}$ anomaly and plotting in the hydrogenous field of the $\mathrm{Fe}-\mathrm{Mn}-(\mathrm{Cu}+\mathrm{Ni}+\mathrm{Co})^{*} 10$ triangular plot established that crusts and nodules are dominantly hydrogenous in their origin. However, diagenesis also had an influence, especially in the growth of nodules as evidenced by the presence of vernadite and higher concentration of $\mathrm{Mn}$. Enrichment of $\mathrm{Ce}$ and $\mathrm{Pt}$ and $\mathrm{Pd}$-depleted chondrite-normalized patterns and high $\mathrm{Pt} / \mathrm{Pd}$ ratio in the crusts and nodules indicate selective extraction of few PGE from seawater. Further, strong positive correlations of PGE ( $\mathrm{Pt}, \mathrm{Ru}$ and $\mathrm{Rh}$ ) with redox-sensitive elements such as $\mathrm{Co}$ and $\mathrm{Ce}$ established that preferential accumulation is caused by the process of surface oxidation when sorbed onto Fe-Mn oxyhydroxides in the crusts and nodules. Pt enrichment in the crusts is lower than in the nodules due to the supply of PGE-depleted diagenetic matter into the nodules and consequent low flux of Pt. On the other hand, nodules and crusts are characterized by non-correlation of $\mathrm{Pd}$ with other trace elements, indicating their non-deposition on ferromanganese deposits, unlike other redox-sensitive elements. Different PGE ratios calculated in the present study established that though PGE are incorporated from seawater into the crusts and nodules, the prime source of Ir and Pd is largely cosmogenic, whereas $\mathrm{Pt}, \mathrm{Ir}$ and $\mathrm{Pd}$ are contributed by AAP ophiolites. Pt enrichment in the crusts ( $\sim 1 \mathrm{ppm}$ compared to $0.8 \mathrm{ppm}$ in the crusts of global oceans) and nodules ( $\sim 0.5 \mathrm{ppm}$ compared to $0.3 \mathrm{ppm}$ in the nodules of global oceans) in the Andaman Sea makes it noteworthy for further exploration.

1. Halbach, P. E., Jahn, A. and Cherkashov, G., Marine Co-rich ferromanganese crust deposits: description and formation, occurrences and distribution, estimated world-wide resources. In Deep-Sea Mining, Springer, Switzerland, 2017, pp. 65-141. 
2. Kuhn, T., Wegorzewski, A., Rühlemann, C. and Vink, A., Composition, formation, and occurrence of polymetallic nodules. In Deep-Sea Mining, Springer, Switzerland, 2017, pp. 23-63.

3. Baturin, G. N., Geochemistry of oceanic ferromanganese nodules. Nauka, Moscow, Russia, 1986.

4. Balaram, V., Mathur, R., Banakar, V. K., Hein, J. R., Rao, C. R. M., Gnaneswara Rao, T. and Dasaram, B., Determination of the platinum-group elements (PGE) and gold (Au) in manganese nodule reference samples by nickel sulfide fire-assay and Tecoprecipitation with ICP-MS. Indian J. Mar. Sci., 2006, 35, 7-16.

5. Usui, A. and Someya, M., Distribution and composition of marine hydrogenetic and hydrothermal manganese deposits in the northwest Pacific. Geol. Soc. London, Spec. Publ., 1997, 119, 177-198.

6. Banakar, V. K., Hein, J. R., Rajani, R. P. and Chodankar, A. R., Platinum group elements and gold in ferromanganese crusts from Afanasiy-Nikitin seamount, equatorial Indian Ocean: sources and fractionation. J. Earth Syst. Sci., 2007, 116, 3-13.

7. Halbach, P., Kriete, C., Prause, B. and Puteanus, D., Mechanism to explain the platinum concentration in ferromanganese seamount crusts. Chem. Geol., 1989, 76, 95-106.

8. Hein, J. R., Koschinsky, A. and McIntyre, B., The global enrichment of platinum group elements in marine ferromanganese crusts. In Extended Abstracts, 10th International Platinum Symposium, (eds Törmänen, T. O. and Alapieti, T. T.), 7, Oulu, Finland, 2005, pp. $98-101$.

9. Koide, M., Stallard, M., Hodge, V. and Goldberg, E. D., Preliminary studies on the marine chemistry of ruthenium. Neth. J. Sea Res., 1986, 20, 163-166.

10. Anbar, A. D., Wasserburg, G. J., Papanastassiou, D. A. and Andersson, P. S., Iridium in natural waters. Science, 1996, 273, 1524-1528.

11. Cabral, A. R.., Sattler, C. D., Lehmann, B. and Tsikos, H., Geochemistry of some marine Fe-Mn nodules and crusts with respect to Pt contents. Resour. Geol., 2009, 59, 400-406.

12. Kubrakova, I. V., Koshcheeva, I. Y., Tyutyunnik, O. A. and Asavin, A. M., Role of organic matter in the accumulation of platinum in oceanic ferromanganese deposits. Geochem. Int., 2010, 48, 655-663.

13. Goldberg, E. D. and Koide, M., Understanding the marine chemistries of the platinum group metals. Mar. Chem., 1990, 30, 249257.

14. Koschinsky, A, Audroing, J. and Hein, J. R., The enrichment of platinum and fractionation of Pt from Pd in marine ferromanganese crusts. In Extended Abstracts, 10th International Platinum Symposium (eds Törmänen, T. O. and Alapie, T. T.), 2005.

15. Baturin, G. N., Konopleva, E. V., Dubinchuk, V. T. and Mel'nikov, M. E., Platinum and gold in the ferromanganese crusts of the Pacific Ocean. Oceanol. Russ. Acad. Sci., 2005, 45, 269276.

16. Glasby, G. P., Incorporation of transition and platinum group elements (PGE) in Co-rich Mn crusts at Afanasiy-Nikitin seamount (AFS) in the equatorial S Indian Ocean. Resour. Geol., 2010, 60, 212-215.

17. Hein, J. R., Conrad, T., Mizell, K., Banakar, V. K., Frey, F. A. and Sager, W. W., Controls on ferromanganese crust composition and reconnaissance resource potential, Ninetyeast Ridge, Indian Ocean. Deep-Sea Res. Part-I, 2016, 110, 1-19.

18. Guan, Y., Sun, X., Ren, Y. and Jiang, X., Mineralogy, geochemistry and genesis of the polymetallic crusts and nodules from the South China Sea. Ore Geol. Rev., 2017, 89, 206-227.

19. Muiños, S. B. et al., Deep-sea Fe-Mn crusts from the northeast Atlantic Ocean: composition and resource considerations. Mar. Georesour. Geotechnol., 2013, 31, 40-70.

20. Asavin, A. M., Kubrakova, I. V., Mel'nikov, M. E., Tyutyunnik, O. A. and Chesalova, E. I., Geochemical zoning in ferromanganese crusts of Ita-Mai Tai guyot. Geochem. Int., 2010, 48, 423445 .
21. Curray, J. R., Tectonics and history of the Andaman Sea region. J. Asian Earth Sci., 2005, 25, 187-232.

22. Surya Prakash, L. et al., Distribution of REEs and yttrium among major geochemical phases of marine $\mathrm{Fe}-\mathrm{Mn}$-oxides: comparative study between hydrogenous and hydrothermal deposits. Chem. Geol., 2012, 312-313, 127-137.

23. Wadhavan, S. K., Hariprasad, M., Dinesh, A. C., Karthikeyan, M., Saju, V. and Drishya, G., Strategising mineral exploration in offshore obvious geological potential (OGP) areas within exclusive economic zone (EEZ) of India. Indian J. Geosci., 2013, 67(2), 191-198.

24. Nozaki, Y., A fresh look at element distribution in the North Pacific. EOS Trans. Am. Geophys. Union, 1997, 78, 221.

25. Bau, M., Schmidt, K., Koschinsky, A., Hein, J., Kuhn, T. and Usui, A., Discriminating between different genetic types of marine ferromanganese crusts and nodules based on rare earth elements and yttrium. Chem. Geol., 2014, 381, 1-9.

26. McLennan, S. M., Rare earth elements in sedimentary rocks; influence of provenance and sedimentary processes. Rev. Mineral. Geochem., 1989, 21, 169-200.

27. Bonatti, E., Kraemer, T. and Abdulla, H. A. N., Classification and genesis of submarine iron-manganese deposits. In Ferromanganese Deposits on the Ocean Floor (ed. Horn, D. R.), National Science Foundation, Washington, USA, 1972, pp. 149-166.

28. Hein, J. R. and Koschinsky, A., Deep-ocean ferromanganese crusts and nodules. In Treatise on Geochemistry (eds Holland, H. D. and Turekian, K. K.), Elsevier, Oxford, UK, 2014, pp. 273-291.

29. Berezhnaya, E. D., Dubinin, A. V., Rimskaya, M. N. and Safin, T. H., Accumulation of platinum group elements in hydrogenous $\mathrm{Fe}-\mathrm{Mn}$ crusts and nodules from the southern Atlantic Ocean. Minerals, 2018, 8, 275.

30. Officer, C. B. and Drake, C. L., Terminal cretaceous environmental events. Science, 1985, 227, 1161-1167.

31. Hein, J. R., Mcintyre, B. and Koschinsky, A., The global enrichment of platinum group elements in marine ferromanganese crusts. Exetended. Abstrct, 2005, 10, 98-101.

32. Ehrenbrink, P. B. and Ravizza, G., The marine osmium isotope record. Terra Nova, 2000, 12, 205-219.

33. Soyol-Erdene, T. O. and Huh, Y., Dissolved platinum in major rivers of East Asia: implications for the oceanic budget. Geochem. Geophys. Geosyst., 2012, 13, 1-13.

34. Cave, R. R., Ravizza, G. E., German, C. R., Thomson, J. and Nesbitt, R. W., Deposition of osmium and other platinum-group elements beneath the ultramafic-hosted Rainbow hydrothermal plume. Earth Planet. Sci. Lett., 2003, 210, 65-79.

35. Hein, J. R., Koschinsky, A. and Halliday, A. N., Global occurrence of tellurium-rich ferromanganese crusts and a model for the enrichment of tellurium. Geochim. Cosmochim. Acta, 2003, 67(6), $1117-1127$.

36. Stueben, D., Glasby, G. P., Eckhardt, J. D., Berner, Z., Mountain, B. W. and Usui, A., Enrichments of platinum-group elements in hydrogenous, diagenetic and hydrothermal marine manganese and iron deposits. Explor. Min. Geol., 1999, 8, 233-250.

37. Hodge, V. F., Stallard, M., Koide, M. and Goldberg, E. D., Platinum and platinum anomaly in the marine environment. Earth Planet. Sci. Lett., 1985, 72, 158-162.

38. Koide, M., Goldberg, E. D., Niemeyer, S., Gerlach, D., Hodge, V., Bertine, K. K. and Padova, A., Osmium in marine sediment. Geochim. Cosmochim. Acta, 1991, 55, 1641-1648.

39. Curray, J. R., Moore, D. G., Lawver, L. A., Emmel, F. J., Raitt, R. W., Henry, M. and Kieckhefer, R., Tectonics of the Andaman Sea and Burma. In Geological and Geophysical Investigations of Continental Margins American Association Petroleum Geologists (eds Watkins, J., Montadert, L. and Dickerson, P. W.), Mem. 29, 1979, pp. 189-198.

40. Awasthi, N., Jyotiranjan, S. R., Ashutosh, K. S., Shraddha, T. B. and Vinai, K. R., Provenance of the Late Quaternary sediments in 
the Andaman. Geochem., Geophys., Geosyst., 2014, 15, 38903906.

41. Prichard, H. M. and Brough, C., Potential of ophiolite complexes to host PGE deposits. In New Developments in Magmatic $\mathrm{Ni}-\mathrm{Cu}$ and PGE Deposits (eds Li, C. and Ripley, E. M.), Geological Publishing House, Beijing, China, 2009, pp. 277-290.

42. Pal, T., Chakraborty, P. P., Gupta, T. D. and Singh, C. D., Geodynamic evolution of the outer-arc forearc belt in the Andaman Islands, the central part of the Burma-Java subduction complex. Geol. Mag., 2003, 140, 289-307.

43. Saha, A., Santosh, M., Ganguly, S., Manikyamba, C., Ray, J. and Dutta, J., Geochemical cycling during subduction initiation: evidence from serpentinized mantle wedge peridotite in the South Andaman ophiolite suite. Geosci. Front., 2018, 9, 17551775 .

44. Pal, T., Chakraborty, P. P. and Ghosh, R. N., PGE distribution in chromite placers from Andaman ophiolite and its boninitic parentage. J. Geol. Soc. India, 2003, 62(6), 671-679.

45. Anders, E. and Ebihara, M., Solar-system abundance of elements. Geochim. Cosmochim. Acta, 1982, 46, 2363-2380.

46. Govett, G. S. J., Rock geochemistry in mineral exploration. In Handbook of Exploration Geochemistry, Elsevier, Amsterdam, The Netherlands, 1983, vol. 3, p. 461 .
47. Naldrett, A. J., Nickel sulfide deposits: classification, composition and genesis. Econ. Geol., 1981, 75, 628-655.

48. Peucker-Ehrenbrink, B., Bach, W., Hart, S. R., Blusztajn, J. S. and Abbruzzese, T., Rhenium-osmium isotope systematics and platinum group element concentrations in oceanic crust from DSDP/ODP sites 504 and 417/418. Geochem. Geophys. Geosyst., 2003, 4, 8911.

49. McDonough, W. F. and Sun, S. S., The composition of the Earth. Chem. Geol., 1995 67(5), 1050-1056.

ACKNOWLEDGEMENTS. We thank Shri. Kshetrimayum Atmajit Singh, Senior Geologist, Geological Survey of India, Kolkata on-board R.V. Samudra Ratnakar for assistance in sampling during the cruise SR-45. We also thank Division of Geochemistry, NGRI, Hyderabad for analysis of PGE. The authors are also thankful to Director General, GSI, Kolkata for permission to publish this paper. We are also thankful to the editor and anonymous reviewers for their constructive suggestions that helped to improve the manuscript.

Received 14 October 2020; revised accepted 14 February 2021

doi: $10.18520 / \mathrm{cs} / \mathrm{v} 120 / \mathrm{i} 11 / 1740-1748$ 